\section{Opinión del lector}

Antonio Bellido Blanco

Museo de Valladolid

Si acudimos a la Ley 16/1985 de Patrimonio Histórico Español, en su artículo 2 encontramos que los valores que definen este concepto de Patrimonio son artisticos, históricos, paleontológicos, arqueológicos, etnográficos, cientificos y técnicos. Son criterios tomados de forma genérica, sin que se marque una medida de valoración a lo que es 0 no es arte, a lo que ha entrado o no en la historia, o a lo que define el carácter de una cultura. Resulta, por tanto, muy dificil determinar legalmente qué forma parte del Patrimonio. En el fondo se dependería de la subjetividad de aquellos técnicos de las administraciones públicas encargados de intervenir en la declaración de BIC o de elaborar otro tipo de inventarios del Patrimonio.

Revisando el texto legal un poco atrás, en el Preámbulo que define su carácter, se ofrece una definición más "etérea" de Patrimonio, aunque seguramente más real. Se defiende aquí que el Patrimonio es una riqueza colectiva y que "su valor lo proporciona la estima que, como elemento de identidad cultural, merece a la sensibilidad de los ciudadanos". Se resalta la acción social que cumple este Patrimonio y el aprecio que se ha generado en torno a él por parte de los ciudadanos. Se trataría de una definición bien distinta a la primera y en la que priman aspectos como las emociones, los sentimientos y las inquietudes de la masa general de los ciudadanos.

Nos encontramos ante dos planteamientos bien distintos, uno de carácter dogmático e impuesto frente a otro más cambiante y voluntario. Uno nace de la necesidad de preservar un legado reconocido por los expertos y pocos más, mientras el otro surge de la enseñanza recibida o del reconocimiento general. Aparentemente es el mismo Patrimonio; pero en la realidad están bien alejados uno del otro.

¿De qué sirve la defensa legal, los inventarios y las declaraciones de BIC cuando todos esos mecanismos no llegan de ningún modo a ser reconocidos por los ciudadanos? Los habitantes de una localidad apenas llegan a reconocer una infima parte de todo el Patrimonio Histórico y Natural que les rodea: varias iglesias, los palacios más monumentales, la estatua de algún personaje ilustre, uno o dos museos, un gran parque, y poco más. El resto del Patrimonio permanece "dormitando" a la espera de que algo lo saque del desconocimiento general.

De este modo es como se destrozan las naves de una fábrica de inicios del siglo $X X$-aunque se pueda conservar una alta chimenea de ladrillo- para levantar un centro cívico, 0 como se arrasa un yacimiento arqueológico preparando la explanación de una nueva urbanización de chalés. $Y$ de la misma manera se muere un anciano gaitero o un constructor de carros sin que más de cuatro personas echen en falta la pérdida de sus conocimientos. 0 se consiente que la reforma de un edificio de viviendas con al menos dos 0 tres siglos de existencia contemple su demolición entera, salvándose sólo su fachada.

No resulta fácil definir qué comprende el Patrimonio. El reconocimiento por parte de los ciudadanos no es constante, influido por campañas de promoción y revalorización 0 por el lento olvido. Ni siquiera los criterios técnicos son suficientes, pues varian, y lo que hoy unos deciden conservar puede que a los pocos años otros decidan que ya no vale, y viceversa. El Patrimonio entendido como aquello que heredamos de nuestros antepasados resulta demasiado extenso, pero quizás sea lo más certero. El problema reside en que sólo valorándolo podremos mantenerlo y mejorarlo. No basta con potenciar elementos patrimoniales concretos, sino que hay que inculcar criterios e inquietudes que no estén manipulados. ¿Quién se atreve con una labor como ésta?

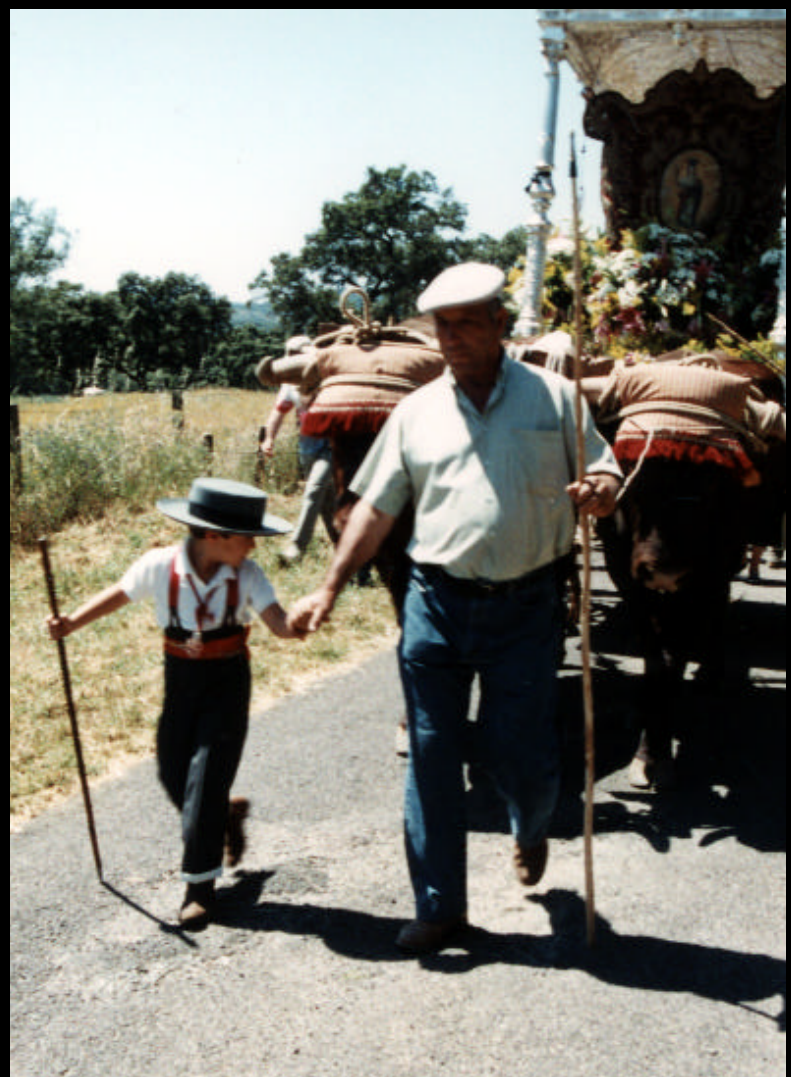

1. Romería de Santa Eulalia en Almonaster la Real, Huelva. Imagen: Carmen Guerrero 